\author{
Joško Božanić \\ Faculty of Humanities and Social Sciences \\ University of Split \\ josko.bozanic@gmail.com
}

\title{
Ethics of the Sea - Experience of the Vis Archipelago Fishermen
}

\author{
Sacrifice, regard, work \\ - those things only can save our country!
}

(Words carved into a stone lintel above the doors of the Public Reading Room in the town of Komiža in the late 19th century).

\begin{abstract}
This paper is based on the author's years-long research on the experience of Vis archipelago fishermen, their ethics and mutual relationships in the extreme conditions of fishing at distant open sea islands of the Adriatic, where they were continously exposed to pirate attacks, open sea elements, with boats powered by wind or man, in small living quarters of a boat and fiercely competing with each other. In such extreme conditions the only answer to the challenge of survival was mutual solidarity, willingness to help one another, the principle of egalitarianism and mutual respect. The author also speaks about the transethnic culture of people living at sea, the phenomenon of the sea as the liquid element which does not divide but rather connects different shores, cultures and languages. Finally, he speaks about the insular world whose most important social principle is work as the basis of survival, sacrificing oneself for the sake of another and high value of each individual, who deserves to be held in esteem through his work and sacrifice in spite of his selfish interests.
\end{abstract}

Keywords: fishing, ethics, Komiža, transethnic culture, the Adriatic sea, Dalmatia

This is an Open Access article distributed under the terms of the Creative Commons Attribution 3.0 PL License (creativecommons.org/licenses/by/3.0/pl/), which permits redistribution, commercial and non-commercial, provided that the article is properly cited. (C) The Author(s), 2015

Publisher: Institute of Slavic Studies, Polish Academy of Sciences

Editor in chief: Jolanta Sujecka

Conception and academic editing of this issue: Maciej Falski 


\section{Dalmatia - Terra Nauta}

7 he eastern Adriatic part of the Illyricum was known by the Romans

1 as Dalmatia. Its etymology probably stems from the Illyrian word delme, meaning sheep, since this domestic animal, characteristic of the inland territory of the Illyricum, was central to the survival of nomadic tribes inhabiting mountanious pastoral regions of the Dinaric karst.

Is the sheep truly a representative symbol of Dalmatia, its very identity? Is the sheep perhaps woven into the history of the most significant Dalmatian historical edifice -Diocletian's Palace? This just might be the case, as was suggested by Split's renowned art historian Joško Belamarić, who put forward a theory that the Roman emperor's palace in Split was not simply a countryside refuge for the weary emperor, but an important factory (ginecej) for the manufacture of military garments made from the wool of sheep from the Dalmatian hinterland. ${ }^{1}$ One thing is for sure - Dalmatia is a twofold land in both a geographical and a cultural sense, and it would be difficult to find an appropriate symbol representing it as a culturally homogenous province.

The mountanious region that spreads along the Dalmatian coast is a geographical divider, splitting Dalmatia into the maritime (Mediterranean) and mountanious (Dinaric) part. Dalmatia is in that sense a territory comprising different cultural mentality matrices that shaped significantly different historical, political and economic circumstances. Figs, olives and seagulls managed to penetrate into the hinterland of Dalmatia, but salted anchovies never made it to the table of its inhabitants. In such a narrow space defined by mountains rising along the coast, opposing mental and cultural matrices remain alive to this day. The clashing mentalities of modern-day Dalmatia are still the same as they were back in the time of caravans and epic poetry.

In an archival document from San Benedetto del Tronto (Italy, 1751) there is mention of certain Nicolo Schiavone, who has sailed from a country metaphorically called Terra Nauta. It is quite certain that the land referred to was Dalmatia, as observed from the perspective of the west Adriatic coast, which was not as indented as Dalmatia, with its numerous islands and a vibrant sailing tradition. Dalmatia was the true maritime land, defined by the maritime space of its archipelago, which provided safe sailing corridors even at the time of year when such feats were quite a risky undertaking on the west Adriatic sandy coastline, devoid of islands, bays, channels and safe ports.

The theory was proposed by Dr.Sc. Joško Belamarić in his doctoral dissertation (Nikolić, 2012). 
Dalmatia is a land of sailing, boatbuilding and excellent sailors, who have, due to skills in maritime trading, erected beautiful towns along the Dalmatian coast and on the islands, towns with small populations but an impressive urban architecture. This same Dalmatia is also a land of fishermen, who were world pioneers of modern fishing, from Tierra del Fuego to Alaska, the Californian San Pedro and Australian Port Lincoln.

In the large Slavic world spreading from the Vladivostok to the Adriatic, Croats are the only Slavic people belonging to the Mediterranean universe that was shaped by the Greek and Roman cultures, two great civilizational pillars of the Western world. Under the influence of these cultures and while maintaining a direct contact with the former centre of the world, Dalmatia has constructed its own identity in architeture, language, gastronomy and lifestyle. The sea is a liquid element - a medium of connection, not isolation. The renowned Croatian Romanist Vojmir Vinja said the following about this phenomenon:

Thousands of years of history of the great sea [the Mediterranean - J.B.] have left their traces: two greatest civilizations that emerged on it left an indelible mark on the coasts, where one bordered the other and where the Southernmost Slavs - the Croats - found their new homeland. As they arrived to the Adriatic coast of the sea, which was then the centre of the world, they soon accepted and adopted the names they encountered, invented their own ones, borrowed from their neighbour, blended their own with their neighbour's, and from it all they produced their own system, in which there was room for theirs and their neighbour's, for the old and the new. [...] The same ancient word [pontos - J.B.] which denoted sea in Greek, served to Romans as an expression for bridge [ponte - J.B.], while the Slavs adopted it [as put - J.B.] to mean 'path.' The sea is indeed both a path and a bridge to a seafarer and a man who lives by the seaside; it is both a dynamic and a static bond, which excludes any self-isolation as well as selfsufficiency" (Vinja, 1986, p. 38).

The outstanding Croatian dialectologist from Split Radovan Vidović writes about the "millennium-long sociolinguistic unity of the inhabitants" alongside the Adriatic, and the common forma mentis, which evolved through "the contact with the other great Mediterranean cultures into an authentic material and cultural unity and identity." He says: "Our Adriatic and its inhabitants, the Adriatic people, have been interconnected by their common lifestyle, the way of thinking, the same seafaring trade, the same vocabulary, the same phraseology, which had permeated not only the everyday lives and language of those who were seafarers by vocation, but likewise the life and language of their families and of the entire communities and places in which they resided. In a word: it was a unique Adriatic community, a koiné, not only in terminological terms, in which 


\section{| Joško Božanić}

people were brought closer together and understood each other regardless of many other differences" (Vidović, 1992, p. 74).

The researcher of the Mediterranean cultures Predrag Matvejević in his Mediterranean Breviary wrote the following: "On the east Adriatic coast, from Istra to the Bay of Kotor, especially in Split, Dubrovnik and Kotor, among various words and coinages [...] there are many loanwords of ItaloVenetian origin, with roots in Latin and sometimes Greek or even some older Balkan substratum. They have been adopted, accepted and adapted in a variety of ways..." (Matvejević, 2006, p. 58). The sea is a path towards the Other, the differing one, which is the reason why the sea does not adhere to the borders of the ethnos. Cultures connected by sea create transethnic identities, communities which those who draw hard lines of continental borders cannot understand.

\section{Poseidon's son complex}

Antaeus, a mythical hero of ancient Greeks, whose father is the sea god Poseidon and mother the earth goddess Gea, was invicible in battle as long as he kept his feet on the ground and remained in contact with the earth. After he found out the secret of Antaeus' invincibility, Hercules lifted him up off the ground during battle and separated him from Mother Earth, the source of his strength, thus successfully overpowering and strangling him.

Those who untie the dock ropes and jump onto a boat, actually jump off of Mother Earth and her firm ground, from their secure foundation in the universe, to set off for the unknown, to far off adventure. To sail means to float above the earth as far away from her as the depth of the sea we sail. To sail means to surrender to the liquid medium, to expose onself to the law of the water, to forget the force tying us to Mother Earth. The one who dared to untie the dock rope and jump onto the boat has to know that the firmness of the deck is illusory and that he should not seek in it a substitute for the firmness of the lost Mother Earth. He should know that, by jumping onto the boat, he is facing a choice: to become a boat or her ballast. The one who set off on a sailing adventure has to know that it is not the boat which is immersed in the water, but the sailor himself, and that the boat's skin is the sailor's own skin. The language of sailors and fishermen is witness to this experience of man's identification with the boat. The sentence "Živko changed his spine," which I have heard on Komižan waterfront, does not mean that fisherman Živko changed his own spine but that Živko changed the worn keel on his boat. When fishermen Pere pulls his boat ashore or launches her into the sea, other fishermen will say: "Pere is ashore," and "Pere is launched." In other words, they speak of it as if fisherman Pere 
himself went ashore or launched himself into the sea. There are plenty of such examples in which language itself tells the story of the boat as a living being, about the boat as a person.

The reason for this affective identification between the man and the boat, imprinted somehwere deep in every sailor's subconsciousness, is the sea. When setting sail, a man embarks into the sea's universe, leaving the familiar terrain which provides a firm ground in the world, and the land governed by men's laws. There is no greater opportunity to know oneself than in the act of surrendering to the law of the large body of salt water. When exposed to the overpowering forces he cannot tame or conquer, in order to survive, the sailor must learn how to adapt to them, how to belong to them, how to make them work to his advantage. During this process, the sailor realizes that his strength does not lie in confrontation but in adjustment, in letting go. The sailor becomes aware of a miracle taking place: forces of nature before which man stands small as a speck of dust suddenly start to assist him in his effort to reach the destination. The sailor frequently tests his own limits of perseverance, and at times when it seems that all boundaries are overstepped and furthest limits reached, a miracle happens. A true miracle indeed: the man has come to know, somewhere deep within himself, something which he had not previously known. When he becomes aware that he is a small speck lost and floating amidst the sea's magnificient vastness, cast at the mercy of the forces of nature, the sailor suddenly comprehends his place in the order of things, his place in the world. Once free of the illusions of strength and importance he attributes to himself, illusions which he maintains also through continental institutions, the sailor comes to know his true power which he had not known before, and this knowledge is the basis of the ethics of those whose destiny is determined by the sea.

Human values that pervaded the lives of the people from the open sea (as F. Fuis would say) were preserved in the memory of old Komižan fishermen. This extremely strenuous and dangerous life, which depleted all reserves of human strength and determination, was defined by very strict codes of conduct, unquestionable principles based on the relationships between members of the fishing communities and the island community at large. These relations and system of values have not changed for hudreds of years, and have secured, more than any other written law, the communities' everyday life and operation on all levels.

\section{A memento for the salvation of the country}

The following sentence was carved into a stone lintel above the entrance doors of the Public Reading Room on Komižan waterfront some hundred 


\section{| Joško Božanić}

years ago: Sacrifice, regard, work - those things only can save our country! This memento on the agora of this fishing world is today the only trace of the former system of values that hadvis formed the foundation of this world for centuries. Today, only words carved into the stone lintel remain, as a warning that has lost its purpose and meaning. We therefore need to exert an effort to interpret the principles which people in this place understood as the conditions for their survival.

This fishing world at the southernmost island front of the Adriatic established the principle of work as its basic ethical norm. Those who did not meet the criterion of dilligence were morally disqualified by the community, and given derogatory attributes: rugo (rugati se, to mock - thus, the one who deserves to be mocked) or lazarun (a Venetianism describing a loser, member of a gang, a social outcast). Those, however, who were dilligent and hardworking became role models, who were featured in stories - beloved and admired community members, who were honoured by having their woven lives into the fabric of oral stories. Fishermen whom I recorded in Komiža in the late 20th century told stories about those accomplished and hardworking community members, some of which dated from the 19th century. The reason these stories had been preserved in the community as long as that, was because they had to provide the suceeding generations of young people with models for identification, in other words, they preached the system of values based on the cult of work and best summarized in the poetic image of the following proverb: It is better to lean one's laborious hands onto a full stomach than leisurely ones onto an empty stomach.

The principle of sacrifice carved into a stone lintel on the Komižan waterfront is comlementary to the meaning of the principle of work. It is an imperative to give up one's own immediate interest in order to help another person. The fishing world hereby described considered this principle the greatest ethical value because it signified a correction of the man's egotistical impetus, a correction which liberated him from the bondage of the selfserving ego and transformed him into a more noble individual.

However, in this world which lived with the sea and off the sea, this principle was also crucial to physical survival. Survival of five fishing crew members aboard the gajeta falkuša fishing boat in the harsh open sea weather was possible only with each member's attempt to give the community more than is expected of others. This was not easy, since everyone was trying to give more than was expected of them. And the one who succeeded in contributing more than others did not feel used but proud to have been able to do so. 
When going sardine fishing, each member of the fishing crew (each drug) had his own specific position and job assigned on the boat. Two crew members were rowing, the third one was pulling the net from the sea, the fourth was folding the net, and the captain coordinated the entire action from the stern. The hardest work was performed by the fisherman who was in charge of pulling the nets out of the sea, especially if the catch was abundant. In such cases, the one who was folding the nets was supposed to ocassionally step in and replace the one lifting the nets. A drug who would ask: "Are you tired? Do you want me to replace you?" was considered a poor drug. That was a poor way to treat a fellow crew member. It was expetced that the one who was supposed to step in and replace another member would get up onto the deck, shout "Venja vamo!" "Give it to me"), take the nets from the hands of the worn out drug and continue his work. The unwritten rule was that the exhausted drug should never reach the state in which he would need to ask for help, because it was assumed that his crew would offer help in time. This was a sign of good camaraderie, which depended on the crew members' awareness of one another. The word drug in the language of the fishermen was not only a term that described a member of this fishing crew. It was the word which summarized an idea of solidarity with other members of the community and sacrifice of one's own interest for the achievement of the common goal. This word summarizes the programme of survival in the harsh conditions of life at open sea.

The principle of regard is the third element of the proverbial triade of the Komižan memento. An act can only be regarded by a society with its own system of values. In a society where the act of work and act of sacrifice occupy a high place on that scale, people who live by these principles are well regarded. They are embedded into stories and the story keeps memory of their work alive. They gain admiration and respect, and become role models. In this fishing world renowned captains gained the attribute of kaparjun. A kaparjun was that individual who would finish first in the Palagružan regatta and who was also outstanding fisherman and sailor. It was an honour to every drug to be a member of a fishing crew headed by kaparjun.

But in this fishing system, represented by the Komižan špurtenjaca (gajeta falkuša's fishing crew), drug is not a hireling, who sells his work on the market. He is not a simple worker by virtue of the fact that he is a hunter participating in a primordial human activity, which includes the risk and unpredictability of adventure, playful joy, and excitement of a shared feat. A member of the fishing crew is not a hired worker but a participant in an adventure. 


\section{| Joško Božanić}

At a falkuša, the crew was kept to a minimum and so each crew member was irreplaceable, equally important for the functioning of the whole. This is the reason why each member shared the same part of the gained profit. Some of the profit was reserved for the fishing tools, which often needed replacement and repair, and also for boat maintenance. The rest of was shared equally by all the crew members. This open sea egality was most pronounced in the fact that even the captain - who owned the boat - would take the same percentage as the fishing crew novice, thus acknowledging the importance of each and every individual, his value and unique contribution. This dignity of a person, stemming from communal regard, is a source of strength for the demands of hard work during open sea fishing, work which frequently exceeded the limits of human capacity.

\section{The law of the open sea}

The institution of public opinion in the island community whose members all knew each other, determined the way of life and defined codes of behaviour even at distant islands, where fishermen lived sometimes for months at a time. In the high season of sardine fishing, as many as five hundred Komižan fishermen crowded the rugged coast of the open sea island of Palagruža. The relentness competition between them, which was most effectively demonstrated during the regatta from Komiža to Palagruža when which these fishermen could row from sunrise to sunset without letting go of their oars, never brought into question the unwritten law of solidarity among these competing crews. If one crew caught plenty of fish, while others returned with empty nets, those who caught fish shared it with the fishless crews. Similar solidarity was expressed in cases when nets were damaged by dolphins - the hard work of net repair was quickly finished because the other fishermen would assist. This unwritten moral law of solidarity, based on mutual respect, has remained intact for centuries. Members of the fishing crew of the gajeta falkuša boat referred to each other in second person plural. In spite of the closeness imposed by the shared living in the smallest of all possible places (a fishing boat), in spite of the fellowship through work which required that the crew acts in coordination like a single organism, as fingers of one hand, in spite of the shared exploits, victories or defeats in the regattas, in spite of the shared dangers in storms and blisters from the countless miles they crossed rowing together, in spite of all of this a principle of distance was in place, which allowed for maintaining the rigour and the discipline necessary for obeying orders.

The captain would shout out: "Hey, fellas!" to his fishing crew, indicating intimacy, fellowship and mutuality. "Hey, fellas, shall we begin?" the 
captain would ask his men, and this question, backed by the authority of responsibility and knowledge, had the weight of an imperative command. The holler "Hey, fellas!," which served to tighten the fishing crew's cohesion, was also used when addressing other groups. This holler was a sign of solidarity, an expression of willingness to assist whenever it was needed.

Each gajeta fishing boat had an extra oar, a so-called spodula, in case another oar broke or the crew needed a sixth oarsman during stormy weather to take the boat from one side of the island to another, since during storm, it was not possible to pull her ashore. The sixth oarsman from another fishing crew would volunteerin such situations, when the boat was in danger and lives of the crew at stake. An oarsman who was not the member of the endangered fishing crew would jump onto the boat from ashore and would help them with the sixth oar to advance through the wind and waves to the safety of the shelter.

Theft was unknown to this fishing world. They never locked their houses, everything they had on Palagruža was available to everyone and when the owner was away, anyone could steal fishing tools and salted fish. However, oral tradition holds no single record or memory of such theft. Even "stealing" the wind was morally inadmissible. Namely, if the boat gaining lead over another one would "intercept" the wind to the disadvantage of the other boat, this was considered a "theft" was condemned by the moral code of the fishing world, even if the boat "stealing" the wind would face no disqualification from the regatta. A boat attempting to gain advantage over another would usually sail below the wind. This world knew no fear of the other, and everyone in this fishing community tried hard to gain and keep the trust of another, offering them more than was expected to be given in return. It is the only way to understand this miracle - that on this pile of rocks in the sea's endless frontier, on Palagruža's rough coast, or volcanic islets of Brusnik and Jabuka, far from civilization, the highest civilizational standard was realized even without written laws and state regulation, without the means of force, and law keepers. There can be only one explanation for this miracle: that all of this complex regulation of life of hundreds of fishermen on a very confined and dangerous space of a small open sea island was based on the sanctity of custom and solidarity with the other.

\section{A poetics of laughter ${ }^{2}$}

But perhaps we should also mention laughter while interpreting this miracle: a dominant type of oral literature in this fishing world is the facenda

See: Božanić (2007, pp. 339-348). 


\section{| Joško Božanić}

- a non-fictional humorous story describing everyday life. These fishermen laugh at each other and themselves. Everything pretentious about human behaviour, every time someone wants to appear different than he is, all that is naive, greedy, stingy, selfish, immoderate, false - falls prey to laughter: on the boat, at the table, on the beach, on the town square. Laughter rings out, softens the stiffness, relaxes the tension and disperses the fog of false importance, reduces the man to his measure and enables him to be reflected in another person, and to see the other person in himself.

At the core of this laughter, ringing throughout the insular world's representative type of narrative - the facenda - is an inversion of the paradox: the ability to recognize the gain in the loss, the loss in the gain, weakness in strength, strength in weakness.

This strength of the inversion, in which paradoxality of thought surprises the linear mind with the way it connects utter opposites, should also be identified in the most important object of this insular world - the gajeta falkuša. This boat was surprisingly humorously designed, in such a way that it resolves a series of contradictory demands. Falkuša is itself also a being of paradox. Because of this, I dare say that the story about the falkuša is not a story about a dead object of a dead world. This story is not finished because this is a story about the challenge of survival that expects to be addressed by each time and age.

\section{References}

Matvejević, P. (2006). Mediteranski brevijar. Zagreb: V.B.Z. studio.

Vinja, V. (1986). Jadranska fauna - Etimologija i struktura naziva (Vol. 1). Split: Logos. Božanić, J. (2007). Poetika smijeha u facendama otoka Visa. Čakavska rič, 35(2), 339-348.

Vidović, R. (1992). Koine pomorskoga anemonimijskoga nazivlja. Čakavska rič, (1), 74.

Nikolić, L. (2012, January 11). Vrijeme je za redefiniranje Dioklecijanove palače. Retrieved November 17, 2015, from http://www.tportal.hr/kultura/ kulturmiks/169688/Vrijeme-je-za-redefiniranje-Dioklecijanove-palace.html

\section{Note}

This paper was delivered as a lecture to students at the Institute of Western and Balkan Studies of Warsaw University on October 13th 2015, and it was realized as part of the project „Adriatic Tale - the Interdisciplinary Research of Adriatic Narratives - ADRIANA.

No conflicts of interest exist. 